\title{
Prescription of antibiotics in community-acquired pneumonia in children: are we following the recommendations?
}

This article was published in the following Dove Press journal:

Therapeutics and Clinical Risk Management

14 June 2016

Number of times this article has been viewed

\author{
Eduardo Jorge da Fonseca \\ Lima ${ }^{1,2}$ \\ Débora Ellen Pessoa Lima ${ }^{3}$ \\ George Henrique Cordeiro \\ Serra ${ }^{2}$ \\ Maria Anaide Zacche $\mathrm{S}$ \\ Abreu e Lima ${ }^{2}$ \\ Maria Júlia Gonçalves de \\ Mello ${ }^{1,2}$ \\ Instituto de Medicina Integral \\ Professor Fernando Figueira - \\ IMIP, Recife, PE, Brazil; ' ${ }^{2}$ aculdade \\ Pernambucana de Saúde - FPS, \\ Recife, PE, Brazil; ${ }^{3}$ Universidade de \\ Pernambuco, Recife, PE, Brazil
}

Objective: To assess the adequacy of antibiotic prescription in children hospitalized for pneumonia in a reference pediatric hospital in Brazil.

Methods: This was a cross-sectional study involving children aged between 1 month and 5 years who were hospitalized between October 2010 and September 2013. The classification of community-acquired pneumonia (CAP) was based on the clinical and radiological criteria of the World Health Organization (WHO). The analysis of antibiotic adequacy was performed according to the main guidelines on CAP treatment, which include the WHO guidelines, Brazilian Society of Pediatrics guidelines, and international guidelines (Pediatrics Infectious Diseases Society, the Infectious Disease Society of America, British Thoracic Society, and Consenso de la Sociedad latinoamericana de Infectología). A multivariate analysis was performed including variables that have statistical significance of $P \leq 0.25$ in the bivariate analysis.

Results: The majority of the 452 hospitalized children were classified as having severe or very severe CAP (85.18\%), and inadequate empiric antimicrobial therapy was started in $26.10 \%$ $(118 / 452)$ of them. Ampicillin was the most used empiric antibiotic therapy $(62.17 \%)$ for pneumonia, followed by a combination of ampicillin and associated with gentamicin. The initially proposed regimen was modified in $29.6 \%$ of the patients, and the most frequent change was the replacement of ampicillin by oxacillin combined with chloramphenicol. The median hospitalization time was 8.5 days, and the lethality rate was $1.55 \%$. There was no statistical difference in adequacy in relation to the severity of pneumonia or degree of malnutrition. In the bivariate analysis, inadequacy of antibiotic therapy regimen was higher in patients undergoing oxygen therapy $(P<0.05)$, which was given to 219 patients (48.45\%). Pleural effusion was observed in 118 patients $(26.11 \%)$ and was associated with higher prescription inadequacy, and it was the only factor that remained in the multivariate analysis (odds ratio $=8.89 ; 95 \%$ confidence interval 5.20-15.01).

Conclusion: Adherence to the main guidelines for antimicrobial therapy according to the childhood CAP was unsatisfactory. Compliance with the guidelines is essential for both the management of pneumonia cases and the decrease in bacterial resistance and it is one of the cornerstone of WHO police of controlling antibiotic resistance.

Keywords: antibiotic therapy, pneumonia, children, health services

\section{Introduction}

Community-acquired pneumonia (CAP) is one of the main causes of mortality in children aged less than 5 years, responsible for $\sim 19 \%$ of all deaths worldwide. ${ }^{1}$ Antibiotic therapy is often empirically initiated, based on the epidemiological knowledge of the main bacterial agents, according to the age-group and clinical severity. ${ }^{2}$

Although there was a decrease in all-cause mortality in children in the decade 2000-2010, including mortality caused by pneumonia, it has been estimated that
Correspondence: Eduardo Jorge da Fonseca Lima

Instituto de Medicina Integral Professor Fernando Figueira, Rua dos Coelhos, 300, Boa Vista Recife, PE, Brazil

Tel +558121224166

Email eduardojorge@imip.org.br
Therapeutics and Clinical Risk Management 2016:12 983-988

983

Dovepress

$f$ in 0

http://dx,doi.org/10.2147/TCRMS101709 (c) (1) (5) 2016 Fonseca Lima et al. This work is published and licensed by Dove Medical Press Limited. The full terms of this license are available at https://www.dovepress.com/terms.php cc. ${ }_{\mathrm{BY}} \mathrm{NC}$ and incorporate the Creative Commons Attribution - Non Commercial (unported, v3.0) License (http://creativecommons.org/licenses/by-nc/3.0/). By accessing the work you hereby accept the Terms. Non-commercial uses of the work are permitted without any further permission from Dove Medical Press Limited, provided the work is properly attributed. For permission for commercial use of this work, please see paragraphs 4.2 and 5 of our Terms (https://www.dovepress.com/terms.php). 
in 2011, CAP accounted for more than 1 million deaths among children, with $\sim 80 \%$ of these deaths occurring in children less than 2 years of age. ${ }^{1}$ According to the Bulletin of the World Health Organization (WHO), Brazil is one of the 15 countries with the highest incidence of CAP, with 0.11 episodes/child/year in children less than 5 years of age, which corresponds to 1.8 million cases/year. ${ }^{2}$

The World Health Organization's definition for CAP and classification of gravity in children are done according to the symptoms and signs presented. ${ }^{3}$ Central cyanosis, severe difficulty for breathing, and/or inability to drink suggest very severe pneumonia.,

The rational choice of empiric antibiotic therapy, essential for clinicians to provide effective care, is based on the etiologic knowledge of CAP, evidence of scientific studies, and consensus of experts. Nowadays, Streptococcus pneumoniae is the main causative agent of bacterial CAP and accounts for one-third of the 5 million deaths due to pneumonia that occur each year in developing countries. ${ }^{5,6}$ Young children, aged less than 2 months, are a special group with regard to CAP etiology; there is a predominance of infection by gram-negative bacteria, beta-hemolytic streptococci, and Staphylococcus aureus in this age-group.,

The WHO and other international scientific societies, such as the Infectious Disease Society of America, British Thoracic Society, and Latin American Society of Pediatric Infectious Diseases, have established guidelines for the management of CAP in children. The Brazilian Society of Pediatrics (SBP) has also made its recommendations, and the Ministry of Health of Brazil has endorsed the proposal of the WHO. ${ }^{8-12}$ Our hospital, a Brazilian reference for pediatric care, has ratified those guidelines for antibiotic therapy for pneumonia and ampicillin or crystalline penicillin are the drugs of choice for the initial treatment of children hospitalized with uncomplicated CAP. ${ }^{13,14}$

Adequate compliance with the protocols, based on guidelines in the management of CAP, has been associated with an increase in the use of narrow-spectrum antibiotics and improved medical practices. ${ }^{15}$ The assessment of compliance with guidelines in pediatric health care services over a 3-year period showed a $44 \%$ increase in the prescription of ampicillin and a decrease from $56 \%$ to $28 \%$ in the use of ceftriaxone. During this same period, there was no increase in the length of stay in hospital or lethality with this narrow-spectrum antibiotic. ${ }^{16}$

The guidelines on CAP treatment are important to rationalize the use of antibiotics and prevent the selection of multidrug-resistant bacteria. Since 2007, the Infectious Diseases Society of America has formally recommended the development of programs for the management of antimicrobials improving the surveillance of antibiotic use in health care institutions. ${ }^{16}$ In 2011, WHO established a policy package to combat antimicrobial resistance where regulate and promote rational use of medicines and ensure proper patient care is one of the cornerstones of this policy but emphasized in 2014 that the resistance to common bacteria has reached alarming levels in many parts of the world. ${ }^{17,18}$

Studies in Brazil have shown that in most cases there is no standardized protocol for the management of acute respiratory infections, which suggests that the quality of care for a child with acute respiratory infection can be improved through an increase in training and supervision of health care professionals, raising their awareness of the abusive and negligent use of antibiotics. ${ }^{19-21}$ Studies that assess the prescription of antibiotics within the health care service networks are useful to detect preventable inadequacies in the care of children with pneumonia., ${ }^{1,22}$

\section{Methods}

This was a cross-sectional study with secondary data involving children aged 1-60 months hospitalized for pneumonia between October 2010 and September 2013 in the wards and pediatric intensive care unit of Instituto de Medicina Integral Professor Fernando Figueira (IMIP). IMIP is the main reference hospital for pediatric inpatients in the city of Recife (northeast Brazil) and exclusively attends to the National Health System (SUS) users.

Sociodemographic, clinical variables, and variables related to the adequacy of antibiotic prescription in childhood CAP were analyzed.

The diagnosis of pneumonia was based on the clinical and radiological criteria established by the WHO and Brazilian Guidelines on Childhood Community-Acquired Pneumonia, 2007. ${ }^{3,4}$ Until 2013, the WHO classified pneumonia in children who present with cough and difficulty breathing accompanied by fever as follows: 1) pneumonia: fast breathing ( $\geq 60$ breaths per minute in children less than 2 months of age, $\geq 50$ breaths in children aged between 2 months and 1 year, and $\geq 40$ breaths in children between 1 and 4 years of age) and the presence of fine crackles on lung auscultation; 2) severe pneumonia: subcostal retraction or stridor in addition to criteria established for pneumonia; and 3 ) very severe pneumonia: inability to drink, intense difficulty in breathing (eg, apnea or involuntary head movements), and central cyanosis in addition to the criteria established for severe pneumonia. . $^{3,4} 8$

Image assessment was performed by two independent radiologists according to the standardization proposed by the WHO for epidemiological studies, including the presence of 
interstitial infiltrate as an indicator of pneumonia. ${ }^{23}$ Patients who did not present the clinical or radiological criteria for the diagnosis of pneumonia proposed by the WHO or had concomitant heart disease, nephropathy, neuropathy, hemoglobinopathy, hepatopathy, immunodeficiency, cystic fibrosis, and congenital lung malformations were excluded. Patients with hospital-acquired pneumonia were also excluded.

The sociodemographic variables included age, sex, and family income relative to the minimum wage (the lowest remuneration that Brazilian employers may legally pay to workers) and the mother's level of education defined by years of schooling.

Guidelines for the management of CAP in children recommend age-specific antibiotic therapy regimens; so, we divided the sample into two age-groups as reported usually in the guidelines: children aged less than 2 months and those aged 2-60 months but we also grouped in younger than 1 year. ${ }^{4,8}$

Among the clinical variables studied were low birth weight $(<2,500 \mathrm{~g})$ and child's nutritional status at hospital admission according to weight-for-age WHO Child Growth Standards (2006) based on $z$ score as adequate $(-2<z$ score $<+2)$, moderately malnourished $(-3<z$ score $<-2)$, and severely malnourished $(z$ score $<-3) .{ }^{24}$

The adherence to guidelines focused on first antibiotic choice and prescription modality, duration of antibiotic therapy, and antibiotic choice in case of treatment modification. In severe pneumonia, the use of either a combination of ampicillin and aminoglycoside or a third-generation cephalosporin alone was considered adequate for children less than 2 months old, and the use of ampicillin or crystalline penicillin was deemed adequate as the first therapeutic choice for children more than 2 months of age. ${ }^{3,4,8}$

In cases of very severe pneumonia, the WHO recommends the use of a combination of parenteral ampicillin (or penicillin) with gentamicin or the use of ceftriaxone alone, whereas the SBP suggests the use of oxacillin combined with chloramphenicol or ceftriaxone given alone. In the present study, both the regimens were considered adequate for the treatment of very severe CAP. In the presence of parapneumonic pleural effusion, the recommended regimens were ampicillin or penicillin or the combination of oxacillin or cephalothin with chloramphenicol., 3,4

Different treatment regimens from those described were considered inadequate. Changes in antibiotic use during hospitalization were also recorded to determine the antibiotic choice in case of treatment modification.

Outcome measurements were analyzed as need of oxygen therapy, development of complications (pleural effusion), length of stay in hospital, and final outcome (discharge or death).

Data were compiled and analyzed using the MS Excel and Epi Info software version 7.0 (Centers for Disease Control and Prevention [CDC], Atlanta, GA, USA). The Statistical Package for Social Sciences software program, version 20.0 (IBM Corporation, Armonk, NY, USA), was used throughout the statistical analysis. Frequency distribution was calculated, and the prevalence ratio for the adequacy of empiric antibiotic was estimated using the chi-square test or Fisher's exact test as appropriate. Variables associated at a level of $P \leq 0.25$ in the bivariate analysis were then included in a multivariable model. A multivariable logistic regression was conducted in accordance with the backward stepwise procedure, and the final model included variables significant at the $5 \%$ level.

This study was approved by the Research Ethics Committee of IMIP (number 3863-13). Written informed consent was obtained from the parents or guardians of all participants.

\section{Results}

In this study, $51.77 \%$ of the 452 enrolled children were boys; 187 (41.37\%) were younger than 1 year including 39 (8.63\%) younger than 2 months. Frequency distributions of variables are shown in Table 1.

Of the 452 patients, 385 (85.18\%) were classified as having severe or very severe pneumonia. Table 2 shows some

Table I Sociodemographic variables of children aged I-60 months hospitalized for CAP at IMIP, Recife, 2010-2013

\begin{tabular}{|c|c|c|}
\hline Variable & $\begin{array}{l}\text { Absolute frequency } \\
(n=452)\end{array}$ & $\begin{array}{l}\text { Relative frequency } \\
\%\end{array}$ \\
\hline \multicolumn{3}{|l|}{ Sex } \\
\hline Male & 234 & 51.77 \\
\hline Female & 218 & 48.23 \\
\hline \multicolumn{3}{|c|}{ Age (months) } \\
\hline$<12$ & 186 & 41.15 \\
\hline $12-59$ & 266 & 58.85 \\
\hline$<2$ & 39 & 8.63 \\
\hline $2-59$ & 413 & 91.37 \\
\hline \multicolumn{3}{|c|}{ Family income (minimum wage) ${ }^{*, \#}$} \\
\hline$<1$ & 26 & 6.48 \\
\hline $1-2$ & 198 & 49.38 \\
\hline $2-3$ & 159 & 39.65 \\
\hline$\geq 3$ & 18 & 4.49 \\
\hline \multicolumn{3}{|c|}{ Birth weight (g) } \\
\hline$<2,500$ & 47 & 11.33 \\
\hline$\geq 2,500$ & 368 & 88.67 \\
\hline \multicolumn{3}{|c|}{ Maternal education (years of schooling) ${ }^{\Delta}$} \\
\hline$\geq \mathrm{II}$ & 270 & 61.64 \\
\hline$<\mathrm{II}$ & 168 & 38.36 \\
\hline
\end{tabular}

Notes: *Minimum wage: the lowest remuneration that Brazilian employers may legally pay to workers, which was US\$210-230 at the time of the study; \#data missing for 5 I patients; ${ }^{\#}$ data missing for 37 patients; ${ }^{4}$ data missing for 14 patients. Abbreviations: CAP, community-acquired pneumonia; IMIP, Instituto de Medicina Integral Professor Fernando Figueira. 
Table 2 Clinical aspects and outcome in children aged I-60 months hospitalized for CAP at IMIP, Recife, 20I0-20I3

\begin{tabular}{lll}
\hline Variable & $\begin{array}{l}\text { Absolute } \\
\text { frequency } \\
\mathbf{n}=\mathbf{4 5 2}\end{array}$ & $\begin{array}{l}\text { Relative } \\
\text { frequency } \\
\%\end{array}$ \\
\hline $\begin{array}{l}\text { WHO classification } \\
\text { Pneumonia }\end{array}$ & 73 & 16.15 \\
$\begin{array}{l}\text { Severe pneumonia } \\
\text { Very severe pneumonia }\end{array}$ & 368 & 81.42 \\
O requirement & 11 & 2.43 \\
Yes & 219 & \\
No & 233 & 48.45 \\
Pleural effusion & & 51.55 \\
Yes & 118 & \\
No & 334 & 26.11 \\
Clinical outcome & & 73.89 \\
Death & 7 & 1.55 \\
Discharge & 445 & 98.45 \\
Length of stay in hospital (days)* & \\
$<4$ & 53 & 11.75 \\
$4-7$ & 175 & 38.80 \\
$8-15$ & 149 & 33.04 \\
$\geq 16$ & 74 & 16.41 \\
\hline Note:Dat msing
\end{tabular}

Note: *Data missing for one patient.

Abbreviations: CAP, community-acquired pneumonia; IMIP, Instituto de Medicina Integral Professor Fernando Figueira; WHO, World Health Organization.

features of the patients' clinical evolution. The length of stay at hospital ranged from 1 to 30 days, and approximately half of the children (50.55\%) were hospitalized for less than 7 days. Supportive treatment with oxygen was necessary for 219 (48.45\%) of them, and 118 (26.11\%) had physical signs and radiological diagnosis of pleural effusion. There were seven deaths, and the mortality rate was $1.55 \%$.

The treatment was classified as adequate in 334 patients (73.89\%). Ampicillin was the most used antibiotic in patients hospitalized for pneumonia (62.17\%), followed by ampicillin combined with gentamicin (7.96\%). Others empiric antibiotic therapies are shown in Table 3.

Table 3 Frequency of empiric antibiotic therapy regimen in children aged I-60 months hospitalized for community-acquired pneumonia at IMIP, Recife, 2010-20I3

\begin{tabular}{lll}
\hline Antibiotic regimen & $\begin{array}{l}\text { Absolute } \\
\text { frequency } \\
(\mathbf{n = 4 5 2 )}\end{array}$ & $\begin{array}{l}\text { Relative } \\
\text { frequency } \\
\%\end{array}$ \\
\hline Ampicillin/Amoxicillin & 281 & 62.17 \\
Ampicillin + gentamicin & 36 & 7.96 \\
Oxacillin + ceftriaxone & 31 & 6.86 \\
Oxacillin + chloramphenicol & 21 & 4.65 \\
Cephalothin + chloramphenicol & $\mathrm{I}$ & 0.22 \\
Ceftriaxone & 17 & 3.76 \\
Others & 65 & 14.38 \\
\hline
\end{tabular}

Abbreviation: IMIP, Instituto de Medicina Integral Professor Fernando Figueira.
Table 4 Frequency distribution and bivariate analysis of some characteristics of CAP and adequacy of empiric antibiotic therapy regimen in children aged I-60 months hospitalized at IMIP, Recife, 2010-2013

\begin{tabular}{|c|c|c|c|}
\hline \multirow[t]{3}{*}{ Variable } & \multicolumn{2}{|c|}{ Empiric antibiotic therapy } & \multirow[t]{3}{*}{$P$-value* } \\
\hline & Adequate & Inadequate & \\
\hline & n (\%) & n (\%) & \\
\hline Age (months) & & & 0.10 \\
\hline$<12$ & $145(43.4 \mid)$ & $4 \mathrm{I}(34.75)$ & \\
\hline $12-60$ & 189 (56.59) & $77(65.25)$ & \\
\hline $\mathrm{O}_{2}$ requirement & & & 0.05 \\
\hline Yes & $153(45.80)$ & $66(55.93)$ & \\
\hline No & I8I (54.20) & $52(44.07)$ & \\
\hline Pleural effusion & & & 0.00 \\
\hline Yes & $5 I(I 5.27)$ & $67(56.77)$ & \\
\hline No & $283(84.73)$ & $5 \mathrm{I}(43.23)$ & \\
\hline
\end{tabular}

Notes: *Chi-square test; $P$-value by Mantel-Haenszel.

Abbreviations: CAP, community-acquired pneumonia; IMIP, Instituto de Medicina Integral Professor Fernando Figueira.

The antibiotic was changed during hospitalization in $29.6 \%$ of the patients; ampicillin was replaced by a combination of oxacillin with chloramphenicol. There was no difference in the adequacy of antibiotic therapy according pneumonia severity.

In the bivariate analysis (Table 4), the inadequacy of empiric antibiotic therapy observed in patients younger than 12 months was higher but without statistical significance ( $P=0.10$ ), and $\sim 30 \%$ of the patients who underwent oxygen therapy received a empiric regimen that was deemed inadequate, in contrast to only $22 \%$ of the patients $(P=0.05)$.

In the multivariate analysis (Table 5), only pleural effusion remained in the model, increasing the possibility of the use of antibiotics as inappropriate (odds ratio $=8.89$ ).

\section{Discussion}

Hospital treatment and antimicrobial drug use are indicated in cases of severe and very severe pneumonia. In the present study, $85.18 \%$ of the cases were classified as having severe or very severe pneumonia, and the indication for hospitalization, as proposed in the $\mathrm{WHO}$ and SBP guidelines, was deemed

Table 5 Multivariate analysis of some characteristics of CAP and adequacy of empiric antibiotic therapy regimen in children aged I-60 months hospitalized at IMIP, Recife, 20 I0-20 I3

\begin{tabular}{lllll}
\hline Variable & $\begin{array}{l}\text { Odds } \\
\text { ratio }\end{array}$ & $\mathbf{z}$ & $\begin{array}{l}\text { P-value } \\
\mathbf{( z )}\end{array}$ & $\mathbf{9 5 \%} \mathbf{~ C l}$ \\
\hline Age $<12$ months & 0.63 & -1.69 & 0.09 & $0.36-1.07$ \\
Pleural effusion & 8.89 & 7.98 & $<0.01$ & $5.20-15.01$ \\
Constant & 0.22 & -7.96 & 0.00 & $0.15-0.32$ \\
\hline
\end{tabular}

Abbreviations: CAP, community-acquired pneumonia; $\mathrm{Cl}$, confidence interval; IMIP, Instituto de Medicina Integral Professor Fernando Figueira. 
adequate. The empiric antimicrobial therapy in $73.89 \%$ of them was also adequate. ${ }^{3,4}$

The hospital where the study was conducted is considered a Brazilian reference in pediatric health care and as a teaching hospital has its own protocols based on the national and international recommendations, which could explain the good results obtained. However, when the adequacy of antibiotic use was related to the severity of the case, the initial regimen was inadequate in approximately half of the patients with very severe pneumonia. This result confirms that even in reference centers, adherence to the protocol is not yet completely satisfactory.

Although pneumonia is an acute disease, it usually progresses to a favorable outcome, and on average, its treatment requires 7 to 10 days. Approximately $50 \%$ of the patients in the present study were hospitalized for up to 7 days and were prescribed oral antibiotics to continue the regimen at home. Studies that evaluate the mean length of stay in hospital have shown it to be 7.5 days. ${ }^{25}$

In the present study, ampicillin was prescribed as the first choice of treatment in $\sim 62.17 \%$ of the patients. The application of the guidelines for the rationalization of antibiotic use is essential in clinical practice. A study that followed 1,033 patients hospitalized in the 12 months before the publication of a guideline aiming to rationalize antibiotic use showed that ceftriaxone was the most prescribed antibiotic (72\%), followed by ampicillin (13\%). A subsequent assessment showed a change in pattern, with ampicillin being the first choice in $63 \%$ of the patients, a result that is similar to that obtained in the present study. ${ }^{26}$

Malnutrition is associated with deficient immune response, infections, and unfavorable outcomes. Although there has been a clear improvement in the nutritional status of Brazilian children in recent years, malnutrition is one of the seven most important factors associated with severe/ very severe childhood pneumonia. ${ }^{27-29}$ Being malnourished at hospital admission (weight-for-age $<-2 z$ score) was not associated with inadequate empiric antibiotic therapy. This result could be explained by the fact that IMIP has a protocol for the management of malnourished patients with an infectious condition. ${ }^{30}$

Although hypoxemia had not remained as a risk factor for the inappropriate use of antibiotics, in recent years, it has been recognized as an important predictor of severe pneumonia and mortality. ${ }^{31}$ The hypoxemia may be not clinically evident, and this sign could be underestimated in our study.

Pulse oximetry is now referred to as the "fifth vital sign" in adults and children, as the appropriate measure is closely related to the partial pressure of oxygen in arterial blood. ${ }^{10}$

Despite the decline of CAP in countries that have introduced conjugate vaccines, paradoxically an increased incidence of complicated pneumonia, characterized by the presence of parapneumonic effusion, empyema, pneumatocele, pyopneumothorax, or necrotizing pneumonia and the association with sepsis, has been observed in recent years. The identification of complicated pneumonia might be more efficient to assess the prognosis than using the WHO classification of gravity. ${ }^{32-34}$

The presence of complications is one of the causes of the failure of childhood CAP treatment, with pleural effusion being the most frequent. In a study with a historical cohort of children hospitalized with pneumonia, the rate of complications was $30.7 \%$, and of these, $98 \%$ were pleural effusions. ${ }^{35}$ In the present study, $26.11 \%$ of the patients presented with pneumonia complicated by pleural effusion. The treatment of pneumonia complicated by drained pleural effusion with a combination of cephalothin/oxacillin and chloramphenicol was considered the adequate regimen. There were significant differences in adequate therapy among those without and with pleural effusion, and this remained in our multivariate analysis demonstrating that these patients need special attention probably due to higher morbidity with the inappropriate use of antibiotics. We must then go further in the investigation about the clinical outcome in these children according to the antibiotic use and may be propose a new approach for this specific group.

The burden of CAP, particularly in developing countries, leads to the need for a constant search for effective strategies for the control and adequate management of the disease. Moreover, the prevalence of infections caused by resistant bacteria has increased in recent years, making this issue one of the most relevant topics in pediatric clinical practice. Despite the various systematic reviews and guidelines on the subject, adherence to the recommendations still needs to be improved.

\section{Disclosure}

The authors report no conflicts of interest in this work.

\section{References}

1. Walker CL, Rudan I, Liu L, et al. Global burden of childhood pneumonia and diarrhea. Lancet. 2013;381:1405-1416.

2. Rudan I, Boschi-Pinto C, Biloglav Z, Mulholland K, Campbell H. Epidemiology and etiology of childhood pneumonia. Bull World Health Organ. 2008;86(5):408-416.

3. WHO. Pocketbook of Hospital Care for Children: Guidelines for the Management of Common Illnesses With Limited Resources. Geneva, Switzerland; 2005. ISBN 924154670 0. Available from: http:// whqlibdoc.who.int/publications/2005/9241546700.pdf. Accessed January 12, 2016. 
4. Diretrizes brasileiras em pneumonia adquirida na comunidade em pediatria [webpage on the Internet]. J Bras Pneumol. 2007;33:31-35. Available from: http://www.scielo.br/scielo.php?script=sci_arttext\&pid=S180637132007000700002\&lng=en. Accessed January 12, 2016.

5. Scott JAG, Wonodi C, Moïsi JC, et al. The definition of pneumonia, the assessment of severity, and clinical standardization in the Pneumonia Etiology Research for Child Health study. Clin Infect Dis. 2012; 54(Suppl 2):S109-S116.

6. Rodriguez JC, Filho LVFS, Bush A. Diagnóstico etiológico das pneumonias -Uma visão crítica. J Pediatr (Rio J). 2002;78(Suppl 2): S129-S140.

7. Clara W, Armero J, Rodriguez D, et al. Estimated incidence of influenzavirus-associated severe pneumonia in children in El Salvador, 2008-2010. Bull World Health Organ. 2012;90(10):756-763.

8. WHO. Recommendations for Management of Common Childhood Conditions: Newborn Conditions, Dysentery, Pneumonia, Oxygen Use and Delivery, Common Causes of Fever, Severe Acute Malnutrition and Supportive Care. World Health Organization; 2012. ISBN 97892 4 150282 5. Available from: http://apps.who.int/iris/bitstream/10665/ 44774/1/9789241502825_eng.pdf. Acessed January 12, 2016.

9. John SB, Carrie LB, Samir SS, et al. The Management of CommunityAcquired Pneumonia in Infants and Children Older Than 3 Months of Age: Clinical Practice Guidelines by the Pediatrics Infectious Diseases Society and the Infectious Disease Society of America. Pediatric Community Pneumonia Guidelines, 2011.

10. Harris M, Clark J, Coote N, et al. British Thoracic Society guidelines for the management of community acquired pneumonia in children: update 2011. Thorax. 2011;66(Suppl 2):1-23.

11. Consenso de la Sociedad latinoamericana de Infectología sobre Neumonía adquirida en la comunidad. SLIPE. 2010;24(94):1-5.

12. Nascimento CMC, Marques HHS. Recomendação da Sociedade Brasileira de Pediatria para antibioticoterapia em crianças e adolescentes com pneumonia comunitária. Rev Panam Salud Publica. 2004;15(6): 380-387.

13. March MFBP. Pneumonias agudas. In: Ferreira OS, Maggi RS, Correia JB, editors. Fernando Figueira: Pediatria. 4th ed. Rio de Janeiro: Medbook; 2011:1448-1458.

14. Rego JC, Batista TD. Pneumonias. In: Lima EJF, Araújo CAFL, Prado HVFM, editors. Emergências Pediátricas. Rio de Janeiro: Medbook; 2011:362-368.

15. Neuman MI, Hall M, Hersh AL, et al. Influence of hospital guidelines on management of children hospitalized with pneumonia. Pediatrics. 2012;130:823-830.

16. Smith JM, Kong M, Cambon A, Woods CR. Effectiveness of antimicrobial guidelines for community-acquired pneumonia in children. Pediatrics. 2012;129:1326-1333.

17. Health Policy Brief: Antibiotic Resistance, Health Affairs; 2015. Available from: http://www.who.int/world-health-day/2011/ policybriefs/en/. Accessed January 12, 2016.

18. WHO. Antimicrobial Resistance. Geneva, Switzerland; 2015. ISBN 978 924156474 8. Available from: http://apps.who.int/iris/bitstream/10665/ 112642/1/9789241564748_eng.pdf?ua=1. Accessed January 12, 2016.

19. Pacheco AJ, Souza R de P, Prado TC de M, Garcia JAD, Loyola YC de S. Utilização de Antimicrobianos para o Tratamento de Infecções Respiratórias em Crianças Atendidas em uma Instituição de Saúde do Estado de Minas Gerais. Rev. Ciências em Saúde. 2011;1(3):1-8.
20. Caldeira AP, França E, Goulart EAM. Mortalidade infantil pós-neonatal evitável: o que revelam os óbitos em domicílio. Rev Bras Saúde Matern Infant. 2002;2:263-274

21. Cunha AJLA. Manejo de infecções respiratórias agudas em crianças: avaliação em unidades de saúde do Rio de Janeiro. Cadernos de Saúde Pública. 2002;18(1):55-61.

22. Dagan R, Bhutta ZA, de Quadros CA, et al. The remaining challenge of pneumonia: the leading killer of children. Pediatr Infect Dis J. 2011; 30(1):1-2.

23. Cherian T, Mulholland EK, Carlin JB, et al. Standardized interpretation of pediatric chest radiographs for the diagnosis of pneumonia in epidemiological studies. Bull World Health Organ. 2005;83(5): 353-359.

24. World Health Organization. WHO Child Growth Standards based on length/height, weight and age. Acta Paediatr Suppl. 2006;450:76-85.

25. Lassi ZS, Das JK, Haider SW, Salam YA, Ghazi KA, Bhutta ZA. Systematic review on antibiotic therapy for pneumonia in children between 2 and 59 months of age. Arch Dis Child. 2014;99(7): 687-693.

26. Newman RE, Hedican EB, Herigon JC, Williams DD, Williams AR, Newland JG. Impact of a guideline on management of children hospitalized with community-acquired pneumonia. Pediatrics. 2012;129(1): 597-604.

27. Wonodi CB, Deloria-Knoll M, Feikin DR, et al. Evaluation of risk factors for severe pneumonia in children: the Pneumonia Etiology Research for Child Health Study. Clin Infect Dis. 2012;54(Suppl 2): S124-S131.

28. Magalhães AE, Martins PL, Rodrigues CR, Moreira BS. Associação entre tempo de internação e evolução do estado nutricional de crianças internadas em um hospital universitário. Demetra; 2013; 8(2);103-114. Available from: http://www.e-publicacoes.uerj.br/index.php/demetra/ article/view/5573/5139\#.VzNhMtIrLIU. Accessed January 12, 2016.

29. Riccetto AGL, Zambon MP, Pereira ICMR, Morcillo AM. Complicações em crianças internadas com pneumonia: fatores socioeconomicos e nutricionais. Rev Assoc Med Bras. 2003;49(2):191-195.

30. Rocha GA, Rocha EJ, Martins CV. The effects of hospitalization on the nutritional status of children. J Pediatr. 2006;82:70-74.

31. Bewick T, Greenwood S, Lim WS. What is the role of pulse oximetry in the assessment of patients with community-acquired pneumonia in primary care? Prim Care Respir J. 2010;19(4):378-382.

32. Amorim PG, Morcillo AM, Tresoldi AT, Fraga A de MA, Pereira RM, Baracat ECE. Fatores associados às complicações em crianças préescolares com pneumonia adquirida na comunidade. J Bras Pneumol. 2012;38(5):614-621.

33. Martín AA, Moreno-Pérez D, Miguélez SA, et al. Aetiology and diagnosis of community acquired pneumonia and its complicated forms. An Pediatr (Barc). 2012;76(3):162.e1-e18.

34. Yu J, Salamon D, Marcon M, Nahm MH. Pneumococcal serotypes causing pneumonia with pleural effusion in pediatric patients. J Clin Microbiol. 2011;49(2):534-538.

35. Kunyoshi V, Cataneo DC, Cataneo AJ. Complicated pneumonias with empyema and/or pneumatocele in children. Pediatr Surg Int. 2006;22: 186-190.
Therapeutics and Clinical Risk Management

\section{Publish your work in this journal}

Therapeutics and Clinical Risk Management is an international, peerreviewed journal of clinical therapeutics and risk management, focusing on concise rapid reporting of clinical studies in all therapeutic areas, outcomes, safety, and programs for the effective, safe, and sustained use of medicines. This journal is indexed on PubMed Central, CAS,

\section{Dovepress}

EMBase, Scopus and the Elsevier Bibliographic databases. The manuscript management system is completely online and includes a very quick and fair peer-review system, which is all easy to use. Visit http://www.dovepress.com/testimonials.php to read real quotes from published authors. 